\title{
Sexual disorders: demographic and diagnostic profile during one year of a multidisciplinary project
}

\author{
Psychiatric Institute of the College of Medicine of the University of São Paulo - São Paulo, Brazil
}

\begin{abstract}
Taking into consideration a study published 10 years ago on sexual disturbances of students at the University of São Paulo, the importance of the subject is discussed, along with the creation in 1993 of the Sexuality Project at the university hospital of the University of São Paulo School of Medicine. In its first year, this multidisciplinary project attended 140 patients with sexual dysfunctions (associated or not to other clinical manifestations); the majority were younger than 60 years-old, and 80 percent were male.
\end{abstract}

UNITERMS: Sexuality. Sexual disorders. Multidisciplinary assistance. Demographic profile. Diagnosis.

Just over ten years ago, one of us published in this journal the results of a diagnostic study done in conjunction with the HSAC - Health and Social Assistance Coordination of the University of São Paulo.' We observed that 11 ( 10.2 percent) of 107 undergraduates were attended at the Service of Mental Health and Hygiene (SMHH) of HSAC during 1983 due to sexual disorders, ${ }^{2}$ classified as: premature ejaculation ( 5 students); impotence ( 3 students); frigidity (1); homosexuality (1); and bisexuality (1).

\section{Adress for correspondence: \\ Carmita Helena Najjar Abdo}

R. Pascal, 181, apto. 41

São Paulo/SP - Brasil - CEP 04616-001
Ten of these students were male, although 58 of the total of 107 patients were female and 49 were male. One bisexual student, who related equally to both sexes, was upset with this condition, although it was not in the Disease Classification. All 11 students were not married and their ages varied from 19 to 34 years. This data formed a larger sexuality study among students of the University of Sāo Paulo enrolled in the SMHH from 1977 to $1994 .^{3}$

Due to the importance of this issue and its repercussion, we created in 1993 the SEXUALITY PROJECT (PRO-SEX), in the Psychiatric Institute of the University Hospital of the College of Medicine of the University of São Paulo.

It is a multidisciplinary team formed in the Psychiatric Institute by psychiatrists, urologists, gynecologists, and psychologists veered to the assistance, teaching and research of sexuality disorders. 
Table 1

Clinical manifestations in men

\begin{tabular}{lrr}
\hline Manifestation & Number & $\%$ \\
\hline Premature ejaculation & 47 & 43.9 \\
Erection disorder & 44 & 41.1 \\
Decrease in pleasure & 2 & 1.9 \\
Transsexual & 2 & 1.9 \\
Other sexual disorders & 3 & 2.8 \\
Psychic and behavior disorders & 2 & 1.9 \\
associated with sexual development & & \\
and orientation (1) & & \\
Personality disorders & & \\
Episode of depression & 3 & 2.8 \\
Non-specified anxiety episode & 2 & 1.9 \\
Excessive intake of tranquilizers $^{*}$ & 5 & 4.7 \\
Deficiency in intelligence* $^{*}$ & 1 & 0.9 \\
Chronic psychotic disorder $^{*}$ & 1 & 0.9 \\
Manic episode $^{*}$ & 1 & 0.9 \\
Social phobia* $^{*}$ & 1 & 0.9 \\
Anxiety $^{*}$ & 1 & 0.9 \\
Total $^{*}$ & 1 & 0.9 \\
\hline
\end{tabular}

* No associated sexual disorder

**Secondary sexual disorder

*** Patients with more than one psychiatric disorder

This report wishes to present a demographic and diagnostic profile of the population attended by the PROSEX during its first year of existence (November 1993 November 1994).

Other aspects and a detailed description of the Project will be published in the future. ${ }^{4}$

These are the results: 176 patients went through initial screening, all from the state of São Paulo, and 140 began treatment. One-hundred and sixteen ( 82.9 percent) patients were male and 24 (10.1 percent) were female.

The age of males varied from 18 to 75 years (mean $=37.8$ ), while the age of females varied from 19 to 67 years (mean $=35.2$ years). In both groups, most of the
Table 2

Clinical Manifestations in women

\begin{tabular}{|c|c|c|c|}
\hline Manifestation & Number & $\%$ & \\
\hline Orgasm disorder & 17 & 73.9 & \\
\hline Decrease in pleasure & 2 & 8.7 & \\
\hline Pain during intercourse & 2 & 8.7 & \\
\hline Egodistonic homosexuals & 1 & 4.3 & \\
\hline Vaginism & 1 & 4.3 & \\
\hline $\begin{array}{l}\text { Non-specified personality } \\
\text { disorder }\end{array}$ & 1 & 4.3 & \\
\hline Total & 24 & 104.2 & ** \\
\hline
\end{tabular}

*No associated sexual disorder

**one patient with 2 psychiatric manifestations

patients seeking treatment were under 60 years $(\mathrm{male}=$ 92.2 percent, female $=91.6$ poercent $)$.

Forty-nine men (42.2 percent of the male group) and 13 ( 54.2 percent) women were married; 54 (46.6 percent) men and 9 (37.4 percent) were single; 4 (3.4 percent) men were widowers and 1 ( 3.4 percent) woman was a widow; 9 (7.8 percent) men and 1 (4.2 percent) woman was unmarried.

Four (2.9 percent) of the 140 patients attended, all male, had a diagnosed organic sexual disorder; erection disorders due to peripheral circulation involvement, caused by diabetes mellitus ( 2 cases); and erection disorders due to atherosclerosis (2 cases). Clinical manifestations for males and female are shown in Tables 1 and 2.

This data shows the importance of and urgency for courses on sexuality (both normal and pathologic) in our medical schools. One of the objectives of the SEXUALITY PROJECT is to offer doctors from several areas a broader view of mental and behavior disorders, than is given by the International Disease Classification. ${ }^{5}$ 


\section{Resumo}

Através da reapresentaçăo de levantamento dos distúrbios sexuais de alunos da Universidade de Sāo Paulo - publicado há dez anos - discute-se a importância do assunto e a criação do Projeto Sexualidade do Hospital das Clinicas da Faculdade de Medicina da Universidade de São Paulo. Este, de caráter multidisciplinar, atendeu, no primeiro ano, a 140 pacientes, a maioria abaixo de 60 anos e com disfunçōes sexuais (associadas ou nāo a outras manifestaçōes clinicas). Do total, $80 \%$ eram do sexo masculino.

\section{REFERENCES}

1. Abdo CHN. Sexualidade: relevância no meio universitário. Rev Paul Med 1984;102(6):282.

2. OMS - Manual da Classificação Estatística Internacional de Doenças, Lesões e Causas de Óbitos (revisão de 1975). Ed. Independência Brasília, 1985.
3. Abdo CHN. Aspectos da Sexualidade de uma população universitária. Tese de Doutoramento, Departamento de Psiquiatria - FMUSP, São Paulo 1989.

4. Abdo CHN \& Oliveira SRC. O primeiro ano do Projeto Sexualidade (em elaboração).

5. OMS - Classificação de Transtornos Mentais e de Comportamento da CID-10: descrições clínicas e diretrizes diagnósticas. Porto Alegre: Artes Medicas, 1993. 